\title{
Erratum: Basik et al. Microbial Degradation of Rubber: Actinobacteria. Polymers 2021, 13, 1989
}

\author{
Ann Anni Basik ${ }^{1,2}\left(\mathbb{D}\right.$, Jean-Jacques Sanglier ${ }^{2}$, Chia Tiong Yeo ${ }^{2}$ and Kumar Sudesh ${ }^{1, *(D)}$ \\ 1 Ecobiomaterial Research Laboratory, School of Biological Sciences, Universiti Sains Malaysia, \\ Gelugor 11800, Penang, Malaysia; annbasik@gmail.com \\ 2 Sarawak Biodiversity Centre, Km. 20 Jalan Borneo Heights, Semengoh, Kuching 93250, Sarawak, Malaysia; \\ jjsanglier.esperanza@gmail.com (J.-J.S.); cyeo@sbc.my (C.T.Y.) \\ * Correspondence: ksudesh@usm.my; Tel.: +60-4-6534367; Fax: +60-4-6565125
}

check for

updates

Citation: Basik, A.A.; Sanglier, J.-J.; Yeo, C.T.; Sudesh, K. Erratum: Basik et al. Microbial Degradation of Rubber: Actinobacteria. Polymers 2021, 13, 1989. Polymers 2021, 13, 2700. https://doi.org/10.3390/

polym 13162700

Received: 28 July 2021

Accepted: 6 August 2021

Published: 13 August 2021

Publisher's Note: MDPI stays neutral with regard to jurisdictional claims in published maps and institutional affiliations.

Copyright: (c) 2021 by the authors. Licensee MDPI, Basel, Switzerland. This article is an open access article distributed under the terms and conditions of the Creative Commons Attribution (CC BY) license (https:// creativecommons.org/licenses/by/ $4.0 /)$.
The authors wish to make the following changes to the published paper [1] as listed below. In the original manuscript, Figure 4:

1. Chemical structures for poly(cis-1,4-isoprene) were wrongly labelled and have been corrected as shown below.

2. B-oxidation should be replaced by oxiAB.

3. oxiAB should be replaced by $B$-oxidation.
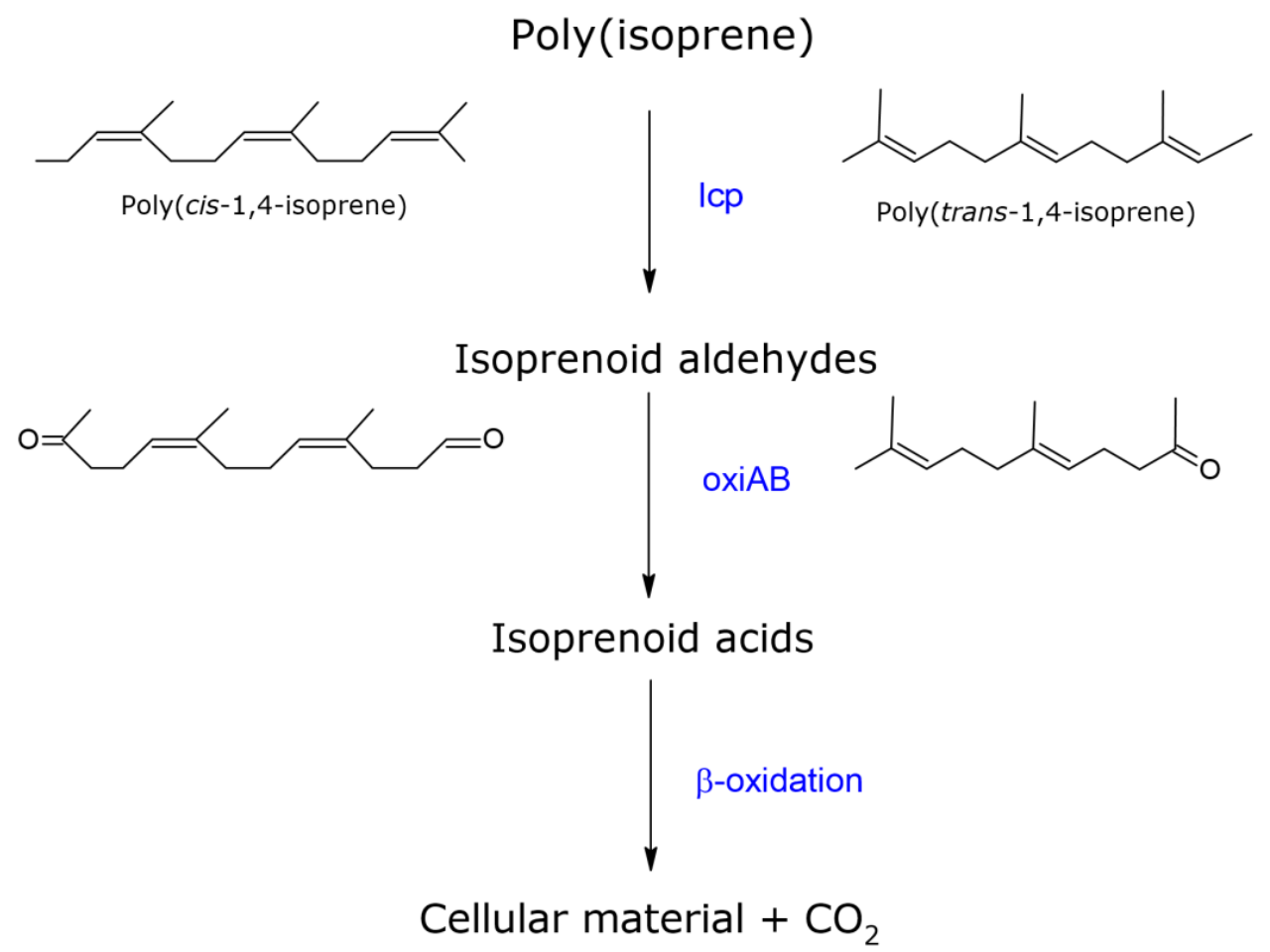

Figure 4. Schematic diagram representing the primary steps of poly(isoprene) biodegradation, followed by oxidization for aldehydes to the corresponding acids, which can be further metabolized via $B$-oxidation. Abbreviations: lcp, latex clearing protein; oxiAB, isoquinoline 1-oxidoreductase subunit alpha and beta.

\section{Reference}

1. Basik, A.A.; Sanglier, J.-J.; Yeo, C.T.; Sudesh, K. Microbial Degradation of Rubber: Actinobacteria. Polymers 2021, 13, 1989. [CrossRef] 